\title{
ПРАВОВІ ЗАСАДИ МІЖНАРОДНОЇ СУДОВОЇ ЮРИСДИКЦІЇ ЗАБЕЗПЕЧЕННЯ БЕЗПЕКИ І ПРАВОПОРЯДКУ НА ТИМЧАСОВО ОКУПОВАНИХ ТЕРИТОРІЯХ ДОНБАСУ
}

\author{
Мацко А. С., Циганов О. Г.
}

\section{ВСТУП}

Міжнародний збройний конфлікт на Донбасі, що розпочався у 2014 році 3 операцій спецслужб Російської Федерації, замаскованих під народне невдоволення, а продовжився у вигляді прямого вторгнення російських військ та їх найманців, організації незаконних збройних формувань та колаборантських «органів влади», є одним із найбільш смертоносних в Європі 3 часів Другої світової війни ${ }^{1}$. Попри зусилля нашої держави 3 мирного врегулювання цього конфлікту, діям української влади бракує стратегічних підходів, комплексності, ефективності та послідовності. Втім, без вирішення цієї найгострішої проблеми сучасної України неможливі ні припинення загибелі наших військових та втрат мирного населення, ні задоволення потреб внутрішньо переміщених осіб, ні відновлення економіки Донбасу та реінтеграції тимчасово окупованих територій, ні, зрештою, забезпечення прискореного економічного зростання нашої держави та здійснення іiі євроінтеграційних устремлінь.

Відповідно до Закону України «Про особливості державної політики із забезпечення державного суверенітету України на тимчасово окупованих територіях у Донецькій та Луганській областях» від 18 січня 2018 року № 2268-VIII цілями державної політики із забезпечення державного суверенітету України на тимчасово окупованих територіях у Донецькій та Луганській областях є: 1) звільнення тимчасово окупованих територій у Донецькій та Луганській областях та відновлення на цих територіях конституційного ладу; 2) захист прав, свобод і законних інтересів фізичних та юридичних осіб; 3) забезпечення незалежності, єдності та територіальної цілісності України 2 .

Правова реалізація державної політики як загалом, так і в окремих сферах - це встановлений системний процес злагодженого механізму, який має внутрішню структуру та функціонує в певному порядку. Тому

\footnotetext{
${ }^{1}$ Війна на Донбасі - в ООН порахували кількість жертв серед цивільних на Донбасі. Слово $i$ Діло. 2019. 4 листопада. URL: https://www.slovoidilo.ua/ ... (дата звернення 21.04.2020).

2 Про особливості державної політики із забезпечення державного суверенітету України на тимчасово окупованих територіях у Донецькій та Луганській областях : Закон України від 18 січня 2018 р. № 2268VIII. Офіціийний вісник Украӥни. 2018. № 19. Ст. 630.
} 
здійснення державної політики щодо відновлення державного суверенітету на тимчасово окупованих територіях окремих районів Донецької та Луганської областей має відбуватися на відповідних правових засадах законодавства України (що є неодмінною вимогою для нашої держави, яка позиціонує себе як правова), а також за участі міжнародної юстиції.

7 серпня 2019 року своїм Указом Президент України В. Зеленський затвердив склад Комісії 3 питань правової політики, яка, зокрема, здійснюватиме напрацювання правових засад щодо створення умов для реінтеграції в єдиний конституційний простір України окупованих територій та населення, що на них проживає $\epsilon^{3}$. Серед основних ідей робочої групи 3 питань реінтеграції тимчасово окупованих територій - необхідність розробки Стратегії реінтеграції окупованих територій із планом дій, який би регулярно переглядався. 3 метою відновлення миру та нормального життя на окупованих територіях, усунення порушень прав наших громадян, притягнення до відповідальності винних за скоєні злочини, відшкодування збитків жертвам війни передбачається підготувати концепцію перехідного правосуддя, імплементувати норми та принципи міжнародного гуманітарного та міжнародного кримінального права. Крім того, один із пріоритетів цієі робочої групи полягає в ратифікації Римського статуту Міжнародного кримінального суду, підписаного Україною ще 20 січня 2000 року.

\section{1. Міжнародна судова юрисдикція як шлях до забезпечення стабільності у постконфліктному українському суспільстві}

Коли йдеться про перехідне правосуддя, то, з одного боку, йдеться про перехід від авторитарного політичного режиму до демократії (як-от у Бразилії, Чилі, Колумбії, Південно-Африканській Республіці або колишніх соціалістичних країнах Європи), а, 3 іншого боку, про перехід від збройного конфлікту до відтворення демократичної держави (наприклад, в Європі після Другої світової війни, колишній Югославії або Руанді). Як вважають фахівці, з 1974 року понад 100 країн у світі мали досвід переходу від авторитарного режиму до демократії або від збройного конфлікту до миру. В обох випадках правосуддя перехідного періоду передбачає відновлення порядку, примирення, відновлення справедливості щодо злочинів минулого, перебудову суспільства ${ }^{4}$.

Варто зазначити, що своєю появою концепція перехідного правосуддя завдячує великою мірою правозахисним кампаніям, які розгорталися в

\footnotetext{
3 Питання Комісії з питань правової реформи : Указ Президента України від 7 серпня 2019 р. № 584/2019. Офіиіийний вісник Президента Украӥни. 2019. № 18. Ст. 696.

${ }^{4}$ Allen T., Douglas B. Closing the door on restitution: The European Court of Human Rights. Transitional Jurisprudence and European Convention on Human Rights: Justice, Politics and Rights (Cambridge, Cambridge University Press, 2011). P. 208-238. DOI: 10.1017/CBO9780511758515.010.
} 
різних країнах сучасного світу як реакція на серйозні порушення прав людини відповідно до гуманітарного права. Водночас концепція перехідного правосуддя виникала не на порожньому місці. Як зазначається в Декларації третього тисячоліття, прийнятої Генеральною Асамблеєю $\mathrm{OOH}$, ця концепція є частиною більш глобального проекту прав людини. Тому повне розуміння концепції перехідного правосуддя можливе лише в контексті теорії поваги до прав людини.

Загалом, якщо проаналізувати підходи, пропоновані науковцями, можна зробити висновок, що перехідне правосуддя характеризує період застосування механізмів, засобів і практик як реакцію на репресії, події конфлікту або війни з метою протидії і подолання наслідків тих порушень прав людини та/або гуманітарного права, які мали місце в минулому 5 .

Отже, під правосуддям перехідного періоду (Transitional Justice) варто розуміти судові та позасудові процеси й механізми, пов'язані зі спробами суспільства подолати наслідки великомасштабних порушень прав людини, в тому числі внаслідок військових конфліктів. Практика перехідного правосуддя, що налічує десятки національних варіантів, спрямована на те, щоб зробити перехід від воєнного часу до мирного якомога гармонійнішим, забезпечивши при цьому справедливе ставлення з боку закону до всіх учасників конфлікту. Саме тому "Transitional Justice" насамперед можна розуміти як справедливість перехідного періоду, аніж власне процес правосуддя.

Забезпечити одночасно справедливість для всіх - процес надзвичайно складний. Тому кожна країна, що пережила збройний конфлікт, розробляє власну модель перехідного правосуддя залежно від властивостей суспільної системи та умов, що історично склалися (враховуючи особливості національної культури та менталітету, етнічних, релігійних і гендерних питань, політичної ситуації та правозастосовчої практики тощо). Незважаючи на те, що нині можна побачити доволі широкий спектр підходів різних країн до розуміння перехідного правосуддя, нині $є$ певний консенсус щодо мети i змісту цього процесу. Основу правосуддя перехідного періоду становлять, як правило, чотири елементи: процес притягнення винних у масових порушеннях до відповідальності та їх покарання за вчинені злочини; процес відшкодування жертвам завданої їм шкоди; процес встановлення правди, повне розслідування порушень, які мали місце в період конфлікту або становили репресивний характер; інституційний процес реформ, який має гарантувати, що такі порушення більше не повторяться.

\footnotetext{
Перехідне правосуддя: погляд українських дослідників. URL: https://ukrainepravo.com/ international_law/public_international_law/tyeuyeshkerye-tuavsftseeya-tsgoyae-tsnualrfenysh-esfokerynkv/ (дата звернення 21.04.2020).
} 
Таким чином, світовий досвід сформував розуміння того, що будь-який вихід із кризи воєнного періоду має передбачати основні чотири напрями:

1) кримінальне судочинство (Criminal prosecutions) - ефективне переслідування винних у скоєнні воєнних злочинів та грубих порушень прав людини; правовий захист жертв збройного конфлікту; вдосконалення законодавства, судової та слідчої практики;

2) відшкодування (Reparations) - створення національних механізмів відшкодування збитків жертвам, виплати їм компенсацій за спричинену фізичну та психічну шкоду, відшкодування збитків, відновлення порушених прав постраждалих від конфлікту, надання їм медичної та психологічної допомоги, а також юридичних та соціальних послуг;

3) констатаиія істини (Truth-telling) - об'єктивна та неупереджена документальна реконструкція подій; розсекречення архівів та формування національного архіву фото-/відеодокументів подій конфлікту; розслідування щодо осіб, які зникли та пропали безвісти;

4) інституиійні реформи (Institutional reforms) - перевірка державних службовців чи кандидатів на відповідну посаду з метою визначення, чи були вони залучені до порушення прав людини під час конфлікту; здійснення реформ сектора безпеки, правоохоронних органів, судового сектору, секторів освіти та ЗМІ.

Зазначені чотири напрями об'єднують практично всі можливі підходи до забезпечення стабільності у постконфліктному суспільстві. Запровадивши ïx, Україна не стане винятком серед країн, які вже пройшли через відповідні історичні катаклізми та використовували власні моделі перехідного правосуддя, починаючи від країн Латинської Америки та закінчуючи країнами, що утворилися на уламках колишньої Югославії́

Необхідність запровадження в Україні елементів перехідного правосуддя підтверджуються не лише революційними подіями останніх років, окупацією Криму i збройним конфліктом, ініційованим державоюагресором на Донбасі, а й суспільним тенденціями й цілою низкою подій, що мали місце напередодні цих буремних днів, які повністю змінили звичне усталене життя мирної країни. Так, упродовж 2010-2013 років в Україні можна було спостерігати кілька трендів: 3 одного боку, реформування кримінального, кримінально-процесуального і військового законодавства, спрямоване на його повну гуманізацію, а 3 іншого зростаюче незадоволення судовою системою та діяльністю органів кримінальної юстиції, що знаходило прояв у чисельних акціях протестів,

\footnotetext{
${ }^{6}$ Перехідне правосуддя - чому в Україні та саме зараз? Українська гельсінська спілка з прав людини, 22 листопада 2017 p. URL: https://helsinki.org.ua/blogs/perehidne-pravosuddya-chomu-v-ukrajini-ta-samezaraz/ (дата звернення 21.04.2020).
} 
організованих громадськістю перед судами, виділення такого суспільноюридичного явища, як «резонансні кримінальні справи», котрі супроводжувалися прискіпливою увагою $3 \mathrm{MI}^{7}$.

На нашу думку, варто погодитися з фахівцями, які вважають, що для забезпечення виходу з кризи воєнного періоду і підтримання стабільності в українському суспільстві, Уряду нашої держави варто прикласти максимум зусиль за певними стратегічними напрямами.

1. Право на правосуддя:

- збір матеріалів для Міжнародного кримінального суду, що доводять факти воєнних злочинів, невиконання державами обов'язків із розгляду справ у зоні конфлікту;

- судові процеси відносно воєнних злочинців;

- надання правової допомоги і ведення стратегічних справ у суді;

- моніторинг судових процесів (методика і практичний досвід);

- удосконалення законодавства і правосуддя під час конфлікту;

- розробка механізмів амністії, законодавче закріплення чіткого тлумачення того, що підпадає під категорію воєнних злочинів, а що - під амністію;

- розробка й адвокація законопроектів порівняно прозорих механізмів звільнення заручників;

- законопроекти про протидію колабораціонізму.

2. Право знати правду:

- розсекречення архівів та відкриття до них доступу;

- документування воєнних злочинів;

- об'єктивна реконструкція подій у зоні конфлікту.

3. Право на компенсачію збитків $і$ допомога постраждалим від конфлікту:

- створення реєстру зруйнованого і пошкодженого майна (основою для якого може слугувати база даних Харківської правозахисної групи);

- розробка законопроектів, спрямованих на надання соціальної допомоги ВПО, житлової допомоги громадянам, житло котрих було зруйновано/пошкоджено/знищено внаслідок збройного конфлікту; відновлення політичних прав;

- формування судової практики (прецедентів) із захисту майнових прав постраждалим від конфлікту;

- збереження пам'яті про жертви конфлікту - візуалізація фактів гибелі мирного населення і комбатантів з усіх сторін конфлікту для публічного доступу («Карта пам’яті», «Книга пам’яті загиблих за Україну»);

\footnotetext{
Перехідне правосуддя: погляд українських дослідників. URL: https:/ukrainepravo.com/ international_law/public_international_law/tyeuyeshkerye-tuavsftseeya-tsgoyae-tsnualrfenysh-esfokerynkv/ (дата звернення 21.04.2020).
} 
- розшук зниклих безвісти в процесі конфлікту.

4. Гарантії неповторення:

- реформа судової системи;

- реформа сектора безпеки - навчання персоналу міжнародних стандартів, тренінги для поліції з питань деокупації;

- підтримка законопроектів у сфері перехідного правосуддя;

- підвищення кваліфікації експертів, котрі працюють із постраждалими від конфлікту у сфері документування та розслідування воєнних злочинів;

- розгляд зарубіжного досвіду 8 .

Щодо зарубіжного досвіду запровадження елементів перехідного правосуддя, то, як зазначалося нами вище, готових уніфікованих рецептів застосування механізмів правосуддя перехідного періоду немає i ïx використання залежатиме, насамперед, від особливостей конкретної країни, iї суспільної системи, умов історичного розвитку. Проте, звичайно, одним із найбільш корисних для України є досвід Балкан, оскільки в цьому випадку події відбувалися відносно нещодавно в Свропі.

Так, аналізуючи запровадження механізмів перехідного правосуддя в Боснії і Герцеговини, варто звернути увагу на досвід «гібридизації» судових процесів у цій країні, за якого національні судді зазвичай займалися питаннями встановлення фактів, а іноземні - питаннями застосування права. При цьому така гібридність зачепила навіть Конституційний суд цієї країни, в якому троє 3 дев'яти членів призначаються головою Європейського суду 3 прав людини після проведення консультацій із Президією Боснії і Герцеговини (своєрідним колективним органом, наділеним функціями глави держави $)^{9}$.

Також заслуговує на увагу досвід з урегулювання збройного конфлікту в Колумбії, який можна вважати одним із найтриваліших у новітній історії людства (упродовж 1964-2016 рр.). Особливістю встановлення миру в цій країні стало розроблення i запровадження системи перехідного правосуддя, яка передбачала, зокрема, прийняття таких законодавчих актів:

- «Про репарації жертвам воєнного конфлікту»;

- «Про реституцію земель» (30 тис. селянських сімей було повернуто землі, колись відібрані бойовиками);

\footnotetext{
8 Правосуддя та справедливість у постконфліктних суспільствах? Європейський досвід та перспективи: Доповіді та дискусії за результатами конференції «Осінні зустрічі», присвяченої темі розвитку перехідного правосуддя в контексті врегулювання конфлікту у східній Україні, м. Берлін, 14-15 листопада, 2018 p. URL: https://helsinki.org.ua/wp-content/uploads/2019/02/UKR-DRA-brochureAutumn-Talks-WEB.pdf (дата звернення 21.04.2020).

9 Перехідне правосуддя: погляд українських дослідників. URL: https://ukrainepravo.com/ international_law/public_international_law/tyeuyeshkerye-tuavsftseeya-tsgoyae-tsnualrfenysh-esfokerynkv/ (дата звернення 21.04.2020).
} 
- «Про амністію» (стосувалася тільки тих учасників бандформувань, які не здійснювали важких злочинів);

- «Про потерпілих» (офіційно в Колумбії було зареєстровано 8,6 млн потерпілих (разом із біженцями), 3 яких 800 тис. осіб отримали компенсації);

- законодавство, що регулює перетворення повстанського руху FARC (Fuerzas Armadas Revolucionarias de Colombia - «Революційні збройні сили Колумбії») на політичний (Fuerza Alternativa Revolucionaria de Colombia «Альтернативна революційна сила Колумбії») (зокрема, політичне крило FARC на 8 років одержало гарантії отримання п'яти місць у Сенаті й Конгресі країни);

- спеціальні правила юрисдикції з питань мирного процесу тощо.

Водночас запровадження механізмів перехідного правосуддя в цій країні вимагало обов'язкового розслідування злочинів, скоєних бойовиками FARC та застосування санкцій до них. Після проходження «комісії правди» під амністію потрапляли тільки ті учасники бандформувань, які не вчиняли тяжких злочинів ${ }^{10}$.

\section{2. Компетенція Міжнародного суду на території України}

У ситуації, коли йдеться про покарання злочинців, що брали участь у збройному конфлікті, перш за все маються на увазі тяжкі злочини. У найрезонансніших або найскладніших випадках такими справами може займатися - Міжнародний кримінальний суд (далі - МКС). Цей суд $\epsilon$ першим правовим інститутом, що діє постійно і в компетенцію якого входить переслідування осіб, відповідальних за геноцид, воєнні злочини і злочини проти людяності, здійснені після набуття чинності Римського статуту (прийнятий на дипломатичній конференції в Римі 17 липня 1998 р. і набрав чинності 31 липня 2002 р.). Станом на вересень 2019 р. Римський статут підписали 155 держав, але ратифікували 122 держави ${ }^{11}$. Цей суд має право діяти на території будь-якої з країн, що його ратифікували, а за додатковими договорами - в інших державах.

Щодо України варто зазначити, що наша країна підписала Римський статут Міжнародного кримінального суду ще 20 січня 2000 р. Водночас перед тим, як віддати договір на ратифікацію до Верховної Ради України, Конституційний суд України за зверненням тодішнього Президента

\footnotetext{
${ }^{10}$ Геращенко I. Спецпоселення і перехідне правосуддя. Як реінтегрують бойовиків FARC, у Колумбії вивчає делегація ВР. Новинарня. 2018. 13 квітня. URL: https://novynarnia.com/2018/04/13/spetsposelennyai-perehidne-pravosuddya-yak-reintegruyut-boyovikiv-farc-u-kolumbiyi-vivchaye-delegatsiya-vr/ (дата звернення: 25.04.2020).

11 Римський статут Міжнародного кримінального суду. Матеріал з Вікіпедії - вільної енциклопедії. URL: https://uk.wikipedia.org (дата звернення 25.049.2020).
} 
України Л. Кучми про перевірку цього статуту на законність встановив (відповідно до доповіді судді М.I. Козубри), що в правових нормах Римського статуту вказується, що МКС доповнює національні правові органи. На підставі зазначеної доповіді, що є дискусійною й по цей час, було прийнято рішення, що Конституція України не визначає юрисдикцію Римського статуту й не передбачає доповнення національних правових органів. Через це МКС роками не мав права розслідувати злочини, вчинені в Україні. Разом із тим у ст. 8 «Міжнародний кримінальний суд» Угоди про асоціацію між Україною, з однієї сторони, та Європейським Союзом, Європейським співтовариством 3 атомної енергії і їхніми державамичленами, з іншої сторони, вказано: «Сторони співробітничають з метою зміцнення миру та міжнародного правосуддя шляхом ратифікації та імплементації Римського статуту Міжнародного кримінального суду 1998 року та пов'язаних із ним документів» ${ }^{12}$.

Водночас Угоду про асоціацію між Україною, $з$ однієї сторони, та Європейським Союзом, Свропейським співтовариством з атомної енергії і їхніми державами-членами, з іншої сторони, вчинену у частині політичних положень (преамбула, стаття 1, розділи I, II, VII) 21 березня 2014 р. в м. Брюсселі та у частині торговельно-економічних і галузевих положень (розділи III, IV, V, VI) 27 червня 2014 р. в м. Брюсселі, яка набирала чинності в перший день другого місяця, що настає після дати здачі на зберігання до Генерального секретаріату Ради Європейського Союзу останньої ратифікаційної грамоти або останнього документа про затвердження Угоди, було ратифіковано з такою заявою: «Зобов’язання України, які випливають із статті 8 Угоди, щодо ратифікації Римського статуту Міжнародного кримінального суду 1998 року будуть виконані після внесення відповідних змін до Конституції України». До набрання ж чинності Угодою варто було тимчасово застосовувати іiі в порядку, передбаченому ст. 486 Угоди ${ }^{13}$. Таким чином, відповідно до ст. 8 Угоди про асоціацію між Україною та Європейським Союзом, а також зазначених положень ратифікації цієї Угоди, наша держава взяла на себе зобов'язання ратифікувати Римський статут МКС після внесення відповідних змін до Конституції України.

Враховуючи викладене та взяті на себе Україною зобов'язання, Парламент України прийняв Закон України «Про внесення змін до

\footnotetext{
12 Угода про асоціацію між Україною, з однієї сторони, та Європейським Союзом, Європейським співтовариством 3 атомної енергії і їхніми державами-членами, 3 іншої сторони. Офіuійний вісник Украӥни. 2014. № 75. Ст. 2125.

${ }^{13}$ Про ратифікацію Угоди про асоціацію між Україною, з однієї сторони, та Свропейським Союзом, Свропейським співтовариством 3 атомної енергії і їхніми державами-членами, з іншої сторони : Закон України від 16 вересня 2014 р. № 1678-VII. Офіційний вісник України. 2014. № 75. Ст. 2125.
} 
Конституції України (щодо правосуддя)» від 2 червня 2016 р. № 1401-VIII, відповідно до якого в ч. 6 нової редакції ст. 124 Конституції України («Правосуддя в Україні здійснюють виключно суди»), передбачив: «Україна може визнати юрисдикцію Міжнародного кримінального суду на умовах, визначених Римським статутом Міжнародного кримінального суду» ${ }^{14}$. У прикінцевих та перехідних положеннях зазначеного Закону вказано, що ч. 6 ст. 124 Конституції України набирає чинності через три роки 3 дня, наступного за днем опублікування цього Закону, тобто 3 30 червня 2019 р.

Варто констатувати, що після внесених змін Законом України від 2 червня 2016 р. № 1401-VIII до ст. 124 Конституції України Верховна Рада України відмовилась ратифікувати Римський статут МКС, мотивуючи, це тим, що Римський статут може бути використаний проти нас же в цій військовій ситуації, відволікати військовослужбовців і всю державу взагалі на абсолютно прогнозовані російські звернення щодо нас у цьому суді в той час, коли Російська Федерація туди не збирається вступати. Таку позицію тоді підтримували також Адміністрація Президента України та РНБО України.

Водночас, попри те, що упродовж двох десятків років Україна так і не ратифікувала Римський статут, Верховна Рада України вже двічі визнавала дію МКС на території України. Перше таке звернення стосувалось подій часів Євромайдану (починаючи 321 листопада 2013 р.), друге - щодо ситуації, яка склалась внаслідок збройної агресії Російської Федерації проти України 327 лютого 2014 р. та вчинення на території України міжнародних злочинів посадовцями Росії та керівниками терористичних «ЛНР/ДНР». При цьому другою заявою українського парламенту до МКС юрисдикція суду була поширена на події за період із 20 лютого 2014 р. й по теперішній час. Ці заяви означають, що, незважаючи на те, що Україна так і не долучилась до країн-учасниць МКС, цей суд може проводити повноцінне розслідування міжнародних злочинів, вчинених на території України з 21 листопада 2013 р., навіть без ратифікації Римського статуту в режимі ad hoc ${ }^{15}$.

Отже, виходить, що ми нині не маємо жодних повноважень, а визнаємо тільки зобов'язання. Ратифікація Римського статуту дала би нам офіційний статус члена Асамблеї держав-учасниць МКС, а з ним - додаткові права (як-от: ставити питання на порядок денний Асамблеї, мати свого суддю, організаційно брати участь у роботі суду). МКС буде розслідувати

\footnotetext{
14 Про внесення змін до Конституції України (щодо правосуддя) : Закон України від 2 червня 2016 р. № 1401-VIII. Офіиіийний вісник Украӥни. 2016. № 51. Ст. 1799.

15 Римський статут - навіщо він Україні? Донбас SOS. 2018. 30 листопада. URL: http://www.donbasssos.org/rimskiy_statyt/ (дата звернення 25.04.2020).
} 
найтяжчі злочини й тоді, коли Україна не матиме бажання або змоги робити це самостійно. Наприклад, у випадку 3 російськими топпосадовцями, адже багато хто очікуватиме від МКС саме покарання представників країни-агресора та допомоги Україні в деокупації Донбасу. Крім того, без ратифікації Римського статуту Україна не має змоги впливати на рішення, які приймаються цим судом, долучатися до процесів як повноправний учасник, тим самим обмежуючи себе ${ }^{16}$.

Внесені Законом України від 2 червня 2016 р. № 1401-VIII зміни до Конституції України в частині правосуддя дають змогу Верховній Раді України вирішувати питання про ратифікацію після 30 червня 2019 р. Це зробить можливим не тільки увійти до системи міжнародного кримінального правосуддя, але й допоможе правоохоронним органам на національному рівні. Ратифікація передбачає також внесення відповідних змін до національного законодавства, що дасть змогу здійснювати кваліфікацію діянь відповідно до міжнародних стандартів.

Нині ситуація в Україні знаходиться на стадії попереднього аналізу Міжнародного кримінального суду: Офіс прокурора МКС досліджує факти та вирішує, чи $є$ підстави та чи достатньо інформації для відкриття розслідування по заявлених злочинах, а також щороку у звітах надає попередні висновки за результатами своєї роботи. Так, відповідно до представлених звітів у 2016-2018 рр. можна виділити таку позицію Офісу щодо подій на сході України:

- має місце поєднання міжнародного збройного конфлікту та неміжнародного збройного конфлікту - як зазначає Офіс прокурора, він не має достатньо доказів того, що на сході має місце тільки збройне протистояння між Російською Федерацією та Україною. Відповідно до отриманої Офісом нині інформації, він може зробити висновок, що міжнародний збройний конфлікт почався 314 липня 2014 p., але паралельно з ним $є$ і внутрішній конфлікт зі збройними групами;

- серед направлених до Офісу прокурора фактів зазначено наймасовіші випадки вчинення таких злочинів: вбивства, руйнування цивільних об'єктів, утримання під вартою, катування та нелюдське поводження, сексуальні та гендерно зумовлені злочини, зникнення людей.

Нині в українських ЗМІ та серед державних органів ходить досить багато чуток про те, що саме означає розслідування МКС ситуації в Україні. Якщо Офіс прокурора прийме позитивне рішення, то:

\footnotetext{
16 Лукашова С. Рябошапка пообіцяв Україні Римський статут і перехідне правосуддя. Що це таке. Украӥнська правда. 2019. 7 вересня. URL: https://www.pravda.com.ua/articles/2019/09/2/7224129/ (дата звернення: 25.09.2019).
} 
- ним будуть визначені наймасштабніші та найжорстокіші злочини, які мали місце протягом усього періоду збройного конфлікту - тобто він не буде братися за розслідування абсолютно всіх ситуацій, тут робота суду має бути підтримана національними органами;

- розслідування буде здійснюватися щодо всіх подій, вчинених на території України, і при цьому не матиме значення, громадянином якої держави є підозрюваний, - суду фактично все одно, хто саме скоїв злочин, навіть якщо він вчиняється на території іншої держави. Тому в контексті ситуації в Україні значення матиме місце вчинення злочину, а не громадянство підозрюваного (щодо цього зауважимо, що Російська Федерація теж не ратифікувала Римський статут та відкликала свій підпис під ним);

- завдання розслідування - сфокусуватися на виконавцях злочинів, які належать до верхівки ієрархії. Тобто фактично МКС зацікавлений у притягненні до відповідальності тих осіб, які віддавали накази до вчинення злочинів, керували їх вчиненням та заохочували їх, наприклад, із метою залякування цивільного населення ${ }^{17}$.

МКС уже 17 років діє в Гаазі, де переслідує винуватців найтяжчих злочинів, таких як геноцид, злочини проти людяності, воєнні, а також злочини агресії. При цьому повноваження МКС не обмежують посади та політичні імунітети: відповідальність можуть понести глави держав чи урядів, військові командири, які керували злочинними операціями.

Після визнання 14 листопада 2016 р. МКС ситуації в Криму та Севастополі рівнозначною міжнародному збройному конфлікту між Росією та Україною президент Російської Федерації В. Путін видав наказ про вихід Росії з-під юрисдикціїі цього суду ${ }^{18}$. Однак, як ми вже зазначали, з 21 листопада 2013 р. МКС може проводити повноцінне розслідування міжнародних злочинів, вчинених на території України представниками країни-агресора, навіть без ратифікації Римського статуту, в тому числі й тоді, коли Україна не матиме бажання або змоги робити це самостійно. Для нашої країни МКС - це інструмент у досягненні такого важливого принципу, як притягнення до реальної відповідальності винних у найтяжчих злочинах. Тому для цього неважливо, щоб Росія ратифікувала Римський статут.

МКС створили для того, аби він виконував функції правосуддя, якщо від цього відмовляється та чи інша держава. Водночас Україну непросто звинуватити в переховуванні своїх громадян від суду: під вартою та 3

\footnotetext{
17 Римський статут - навіщо він Україні? Донбас SOS. 2018. 30 листопада. URL: http://www.donbasssos.org/rimskiy_statyt/ (дата звернення 25.09.2019).

18 Россия вышла из Международного уголовного суда. Интерфакс. 2016. 16 листопада. URL: https://www.interfax.ru/russia/537268 (дата звернення 25.04.2020).
} 
тюремними термінами за приговорами судів України, які набули законної сили, вже неодноразово опинялись колишні військовослужбовці та правоохоронці, що брали участь в АТО. Так, за знущання над затриманими вісьмох представників роти патрульної служби міліції особливого призначення «Торнадо» Головного управління МВС України в Луганській області Оболонський райсуд м. Києва засудив до тривалих термінів позбавлення волі ${ }^{19}$.

Варто наголосити, що сучасна ситуація у світі $є$ дуже напруженою, дедалі частіше спалахують війни, відбуваються міжнародні та внутрішні збройні конфлікти. Війна як форма колективного насилля дедалі потужніше впливає на життя народів та країн. Так, за статистичними даними Міжнародного Комітету Червоного Хреста, за останні п’ять тисяч років відбулося понад 14 тис. війн, у яких загинуло приблизно 5 млрд людей. Вже після Другої світової війни в різних регіонах земної кулі було зафіксовано понад 250 збройних конфліктів ${ }^{20}$.

Разом із тим за останні роки збройні конфлікти стали частішими й тривалішими. Світова громадськість дійшла усвідомлення необхідності обмеження насилля воюючих сторін шляхом узгодженої розробки й укладення договорів, які б регулювали відносини між державами під час збройних конфліктів. Це зумовило створення системи міжнародного гуманітарного права, яке ще іноді називають «право збройних конфліктів», або «право війни». Джерелами права збройних конфліктів є сукупність міжнародно-правових принципів і норм, що регулюють відносини держав та інших суб'єктів міжнародного права в період ведення військових дій, що забороняють чи обмежують засоби ведення війни, які передбачають гуманізацію її методів із метою захисту жертв збройних конфліктів.

Питання міжнародного гуманітарного права, якими б вони не були різноманітними й складними, можуть бути зведені до основної проблеми встановлення рівноваги між вимогами гуманності й військової необхідності. Припустимими є лише такі засоби і методи війни, котрі необхідні для поразки противника. Більшість норм міжнародного гуманітарного права має імперативний характер. На них не поширюється «принцип взаємності», тобто воююча сторона не може відмовитись від їх дотримання навіть у тих випадках, коли інша сторона їх порушує. Отже, державні кордони не можуть зупинити дію міжнародного гуманітарного права й усі воюючі сторони мають його дотримуватись незалежно від політичних та інших міркувань.

\footnotetext{
${ }^{19}$ Суд засудив 8 «торнадівців» до тривалих термінів ув'язнення. Украйнська правда. 2017.7 квітня. URL: https://www.pravda.com.ua/news/2017/04/7/7140625/ (дата звернення: 23.04.2020).

20 Міжнародне гуманітарне право та його норми про захист жертв війни. URL: http://subject.com.ua/textbook/protection/10klas/6.html. (дата звернення: 23.04.2020).
} 


\section{ВИСНОВКИ}

Відновлення контролю над Донбасом і Кримом, повернення до мирного життя на всій території України потребує особливого підходу - концепції перехідного правосуддя, яка має моделювати поведінку української влади після повернення країною-агресором окупованих територій. Зазначена концепція (система) перехідного правосуддя має спиратися на ратифіковані та імплементовані Україною норми й принципи міжнародного гуманітарного та міжнародного кримінального права.

Верховній Раді Україні варто терміново ратифікувати Римський статут Міжнародного кримінального суду та імплементувати норми цього нормативного акта до кримінального законодавства України та Закону України «Про судоустрій і статус суддів», а також визнати юрисдикцію МКС i дати йому змогу співпрацювати в повному обсязі щодо встановлення безпеки і правопорядку на тимчасово окупованих територіях.

Водночас Україні необхідно використовувати всі важелі впливу на міжнародному рівні з метою посилення санкцій проти Росії як країниагресора, в тому числі негайно звернутися до Ради Безпеки ООН із метою прийняття відповідного рішення за порушення норм міжнародного гуманітарного права, а також продовжувати судитися 3 Росією в міжнародних правових інстанціях через російську анексію Криму i збройний конфлікт на Донбасі.

Нині є нагальна потреба розробити Концепцію (Стратегію) деокупації України та реінтеграції Донбасу як національної геополітичної ідеї в розвиток стратегічного курсу на збереження та утвердження європейської ідентичності України. Цей документ має стати інструментом консолідації українського політикуму та суспільства стосовно шляхів і механізмів повернення деокупованих територій Донбасу до України. Стратегія має бути доступною та зрозумілою не лише для кожного українця, але й для всіх міжнародних партнерів України (включаючи Європейський Союз, США, НАТО, ООН), а також для всіх інших глобальних та регіональних міжнародних організацій.

\section{АНОТАЦІЯ}

Статтю присвячено дослідженню правових засад міжнародної судової юрисдикції забезпечення безпеки і правопорядку як на території України, так і на тимчасово окупованих територіях Донбасу. Зазначається, що правова реалізація державної політики щодо відновлення державного суверенітету на тимчасово окупованих територіях має відбуватися на відповідних правових засадах, а також за участі національної доктрини та міжнародної юстиції. 
3'ясовано, що у практиці людства останніх десятиліть як інструмент переходу від збройного конфлікту до миру або від авторитарного режиму до демократії застосовується концепція перехідного правосуддя, яка передбачає відновлення порядку, примирення, відновлення справедливості щодо злочинів минулого, перебудову суспільства. При цьому повне розуміння концепції перехідного правосуддя можливе лише в контексті теорії поваги до прав людини.

Доведено, що практика перехідного правосуддя спрямована на те, щоб зробити перехід від воєнного часу до мирного якомога гармонійним, забезпечивши при цьому справедливе ставлення з боку закону до всіх учасників конфлікту.

Світовий досвід сформував розуміння того, що будь-який вихід із кризи воєнного періоду має передбачати основні чотири напрями перехідного правосуддя: ефективне кримінальне судочинство; створення національних механізмів відшкодування збитків жертвам військових конфліктів; об'єктивна та неупереджена документальна реконструкція подій; інституційні реформи для забезпечення гарантій неповторення.

Встановлено, що МКС є наступником міжнародних трибуналів, який, на відміну від останніх, діє на постійній основі та $є$ правовим інститутом, в компетенцію якого входить переслідування осіб, відповідальних за геноцид, воєнні злочини і злочини проти людяності, скоєні після набуття чинності Римського статуту. Хоча Україна й підписала цей документ ще 20 січня 2000 р., упродовж двох десятиліть так і не спромоглася його ратифікувати, що не дає нашій країні змоги одержати офіційний статус члена Асамблеї держав-учасниць МКС, а з ним - додаткові права.

Доведено, що деокупація та реінтеграція окремих територій України, повернення до мирного життя вимагають застосування перевіреної практикою концепції перехідного правосуддя, яка має моделювати поведінку української влади після повернення країною-агресором окупованих територій. Зазначена концепція має спиратися на ратифіковані та імплементовані Україною норми й принципи міжнародного гуманітарного та міжнародного кримінального права.

\section{ЛІТЕРАТУРА}

1. Війна на Донбасі - в ООН порахували кількість жертв серед цивільних на Донбасі. Слово $i$ Діло. 2019. 4 листопада. URL: https://www.slovoidilo.ua/ ... (дата звернення 21.04.2020).

2. Про особливості державної політики із забезпечення державного суверенітету України на тимчасово окупованих територіях у Донецькій та 
Луганській областях : Закон України від 18 січня 2018 р. № 2268-VIII. Офіиійний вісник України. 2018. № 19. Ст. 630.

3. Питання Комісії з питань правової реформи : Указ Президента України від 7 серпня 2019 р. № 584/2019. Офіційний вісник Президента України. 2019. № 18. Ст. 696.

4. Allen T., Douglas B. Closing the door on restitution: The European Court of Human Rights. Transitional Jurisprudence and European Convention on Human Rights: Justice, Politics and Rights (Cambridge, Cambridge University Press, 2011). P. 208-238. DOI: 10.1017/CBO9780511758515.010.

5. Перехідне правосуддя: погляд українських дослідників. URL: https://ukrainepravo.com/international_law/public_international_law/tyeuyeshkery e-tuavsftseeya-tsgoyae-tsnualrfenysh-esfokerynkv/ (дата звернення 21.04.2020).

6. Перехідне правосуддя - чому в Україні та саме зараз? Українська гельсінська спілка з прав людини. 2017. 22 листопада. URL: https://helsinki.org.ua/blogs/perehidne-pravosuddya-chomu-v-ukrajini-ta-samezaraz/ (дата звернення 21.04.2020).

7. Правосуддя та справедливість у постконфліктних суспільствах? Європейський досвід та перспективи: Доповіді та дискусії за результатами конференції «Осінні зустрічі», присвяченої темі розвитку перехідного правосуддя в контексті врегулювання конфлікту у східній Україні, м. Берлін, 14-15 листопада, 2018 p. URL: https://helsinki.org.ua/wpcontent/uploads-/2019/02/UKR-DRA-brochure-Autumn-Talks-WEB.pdf （дата звернення 21.04.2020).

8. Геращенко I. Спецпоселення і перехідне правосуддя. Як реінтегрують бойовиків FARC, у Колумбії вивчає делегація ВР. Новинарня. 2018. 13 квітня. URL: https://novynarnia.com/2018/04/13/spetsposelennya-iperehidne-pravosuddya-yak-reintegruyut-boyovikiv-farc-u-kolumbiyi-vivchayedelegatsiya-vr/ (дата звернення: 25.04.2020).

9. Римський статут Міжнародного кримінального суду. Матеріал 3 Вікіпедії - вільної енциклопедії. URL: https://uk.wikipedia.org (дата звернення 25.049.2020).

10. Угода про асоціацію між Україною, 3 однієї сторони, та Свропейським Союзом, Свропейським співтовариством з атомної енергії і їхніми державами-членами, з іншої сторони. Офіиійний вісник Украӥни. 2014. № 75. Ст. 2125.

11. Про ратифікацію Угоди про асоціацію між Україною, 3 однієї сторони, та Свропейським Союзом, Свропейським співтовариством 3 атомної енергії і їхніми державами-членами, з іншої сторони : Закон України від 16 вересня 2014 р. № 1678-VII. Офіційний вісник Украӥни. 2014. № 75. Ст. 2125. 
12. Про внесення змін до Конституції України (щодо правосуддя) : Закон України від 2 червня 2016 р. № 1401-VIII. Офіційний вісник України. 2016. № 51. Ст. 1799.

13. Римський статут - навіщо він Україні? Донбас SOS. 2018. 30 листопада. URL: http://www.donbasssos.org/rimskiy_statyt/ (дата звернення 25.04.2020).

14. Лукашова С. Рябошапка пообіцяв Україні Римський статут i перехідне правосуддя. Що це таке. Украйнська правда. 2019. 7 вересня. URL: https://www.pravda.com.ua/articles/2019/09/2/7224129/ (дата звернення: 25.09.2019).

15. Россия вышла из Международного уголовного суда. Интерфакс, 16 листопада 2016 p. URL: https://www.interfax.ru/russia/537268 (дата звернення 25.04.2020).

16. Суд засудив 8 «торнадівців» до тривалих термінів ув'язнення. Українська правда. 2017. 7 квітня. URL: https://www.pravda.com.ua/news/ 2017/04/7/7140625/ (дата звернення: 23.04.2020).

17. Міжнародне гуманітарне право та його норми про захист жертв війни. URL: http://subject.com.ua/textbook/protection/10klas/6.html (дата звернення: 23.04.2020).

\section{Information about authors:} Matsko A. S.,

Ph.D., Associate Professor, Assistant Professor of International Law Institute Management and Law of Yaroslav Mudryi National Law University 77, Pushkinska str., Kharkiv, 61024, Ukraine Tsyhanov O. H., Doctor of Juridical Sciences, Associate Professor,

Chief Researcher State Research Institute of the Ministry of Internal Affairs of Ukraine 4a, Ye. Hutsala Lane, Kyiv, 01011, Ukraine 